\title{
The Impact of Electronic Service Quality's Dimensions on Customer Trust for Online Travel Agencies in India
}

\author{
Sabyasachi DuttaA*, R.K. Chauhann ${ }^{\mathrm{A}}$, Kavita Chauhan ${ }^{\mathrm{B}}$ \\ Received: July 2017 | Accepted: September 2017 \\ DOI: 10.5937/turizam21-16103
}

\begin{abstract}
The ever increasing internet, mobile and credit card penetration along with government efforts to boost tourism, a rising middle class, and an increasing disposable income has ensured that online travel agencies in India are going to enjoy a high growth period. The only way to sustain their business in this highly competitive yet low-margin environment is to acquire and retain customers by improving customer trust and perceived value. The focus is to understand the impact of electronic service quality's dimensions on customer trust while they use online travel agencies in India. It will help online travel agencies to deploy resources correctly to strengthen processes which impact trust the most. Additionally, it will help guide existing online travel agencies and future entrants to have an in-depth understanding of the dimensions of electronic service quality that are information availability, ease of use, graphic style, privacy, and security of their websites.
\end{abstract}

Keywords: trust, electronic service quality, online travel agencies, perceived value, Indian travel market

\section{Introduction}

The Indian travel market has been growing and attracting business, leisure, medical and other travelers. It is estimated that the Indian travel market will be the size of US $\$ 40$ billion by 2020 . Tourism has tremendous potential in India owing to a multi-cultural environment, rich historical heritage, and a variety of climate, terrain and natural beauty. The government of India is actively encouraging and marketing Indian tourism as it views tourism a major employment generator as well as a significant earner of foreign currency. The government has initiated e-tourist visa and visa on arrival facility for several nations to boost inbound tourism. Also,

\footnotetext{
A Lingaya's University, Nachauli, Jasana, Old Faridabad Road, Faridabad, 121002, India

B Department of Management, Jamia Millia Islamia, Jamia Nagar, New Delhi, Delhi, 110025, India

* Corresponding author: sabyasachidutta1@gmail.com
} 
a major focus has been put towards improving infrastructure and creating new tourist spots across many locations to grow tourism further (World Travel and Tourism, 2017).

In the recent years, the online interaction in the tourism industry has become a very crucial step in the customer experience. It has become very important to provide customers with a compelling experience which allows customers to be satisfied with the service. The e-commerce business in India has grown 34\% (Compound Annual Growth Rate) since 2009. The online travel agencies command an enviable $70 \%$ of the total e-commerce market (PwC, 2015). Based on a study conducted by Phocuswright, the online travel market in India is the size of US\$9.1 bn in 2014 which comprises of air travel US $\$ 5.1 \mathrm{bn}$, rail travel US\$3.1bn, hotels o.8bn and others US\$o.1bn.

In the urban clusters, traveling has become a lifestyle choice which has increased the frequency of trips undertaken by the customer within a period of a year. The online travel agencies growth is being facilitated by a significantly low yet fast-growing Internet population of 420 million (in June 2017) which is an indicator of the sector's huge growth potential in India. The convenient choice for travelers is online travel agencies for researching about a destination, gathering information about the language, cuisine, accommodation, location and making the actual bookings. In 2015, online travel agencies commanded a respectable $39 \%$ of the total travel market which means that approximately four out every ten purchases are booked online. It indicates that traditional travel agents in India are not only strong but growing as well. For the online travel agencies to increase their share of the total Indian travel market, they will require improving the convenience for the customer further. It can only happen if there is a greater understanding of what is driving customer satisfaction for the online travel agencies.

Interestingly the Indian travel business continues to be dominated by domestic companies due to their understanding the customer behavior and longstanding presence. In 2015, Oyo rooms revolutionized the concept of room inventory in the budget segment in India. For long the hotel budget segment has been very fragmented and has shown resistance towards technology. Oyo room's successful market share capitalization has led to the entrant of many new competitors as well as forced established online travel agencies to offer similar services. The outbound tourism is also growing significantly with more disposable income as well as more countries offering Indian passport holders visa on arrival facility (Eric, Scott, 2014).

The paper is structured into sections of literature review, proposed model, methodology, results, and conclusion. The objective of the paper is to understand the impact of information availability, ease of use, privacy and security, graphic style and fulfillment on trust. It will help online travel agencies to focus resources on the dimensions which are the most effective. Thus the research questions identified in the paper are as follows:

- What is the impact of trust on perceived value for online travel agencies in India?

- What is the impact of the dimensions of electronic service quality on trust for online travel agencies in India?

- Which dimensions of electronic service quality have a greater impact on trust for online travel agencies in India?

\section{Literature Review}

Academic research papers on online travel agencies with measurable impact were seen only by 2000 . Kaynama and Black (2000) established that traditional instrument of measuring service quality like SERQUAL model was not sufficient to measure the service quality of online 
travel agencies. Rather the paper suggested adapting the SERQUAL model into another assessment tool known as E-QUAL which was specifically developed keeping in mind the electronic commerce business. Wilson (200o) documented the change of trend of customers booking through online travel agencies instead of traditional travel agents. He suggested that products such as books, music, clothing etc. have been early adopters of distributing themselves through online channel likewise the adoption of travel services through online channels in now picking up and there will be an impact on the market share of traditional travel agents.

The issue of price disparity between online travel agencies and traditional travel agencies was mentioned by Lehmann (2001). He empirically proved that the prices of various holiday packages being sold across various online travel agencies are priced more economically owing to the intense price competition. Additionally he noted that due to search inefficiencies there is greater price dispersion across various online travel agencies.

O'Connor (2004) highlighted the privacy concerns of online travel agencies which are threatening their growth. The online travel agencies collect huge amount of personal data as part of their regular operations. He highlighted that though most online travel agencies have mentioned a privacy policy, in most cases the content of such policies are not up to the mark of internationally recognised fair practices. There is sufficient data to indicate that the unprofessional management of personal information by the online travel agencies which is a cause of concern and remedial action should be taken on an urgent basis.

Kim and Lee (2005) identified the dimensions of web service quality between online travel agencies and online travel suppliers. They also compared the dimensions of web service quality between online travel agencies and online travel suppliers. The study found that there are similar dimensions like information content, reputation and security, ease of use and usefulness which are common to both. Information content was found to be the most important dimension for customer satisfaction for online travel agencies and online travel suppliers. Cho and Agrusa (2006) identified the factors which affect the ease of use and usefulness and how these affect the customer attitudes towards online travel agencies. Interestingly the study found that the attitude's of the customer towards the online travel agency has a significant impact on the level of satisfaction of the customer.

Kim et al. (2007) suggested that the most important choice attributes for online travel agencies was finding low fares followed by security. The customers had considered other attributes as well before pointing out their choice. The study also compared seven online travel agencies where-in there were different patterns of customer perceptions of these online travel agencies in terms of finding low fares, ease of use, security and web features. Tsang, Lai and Law (2010) advised that online travel agencies face intense competition hence it is crucial for them to evaluate their electronic service quality. They identified the dimensions of electronic service quality for online travel agencies and established their relationship to purchase intention and customer satisfaction. The six dimensions of electronic service quality identified by them are relationship, appearance, safety, functionality and information quality and content. The most impactful factor for electronic service quality was website functionality. Chiou, Lin and Perng (2011) say that online travel agency websites are visited more for information only and the website can be monitored to discover inconsistency in strategy through a radar chart analysis. Roger-Monzó, Martí-Sánchez and Guijarro-García (2015) suggested that most customers who book through online travel agencies are tech-savvy and selective. The study found that perceived e-service value impacts customer loyalty towards online travel agencies directly.

Based of the above review of the evolution of academic research for online travel agencies it was found that the literature is quite extensive. The online travel agencies have gone through 
tremendous technological advancements and customer trust since 2000. The online travel agencies have grown from a novel concept for convenience to major distribution channel with a significant market share towards the sale of travel products.

One of the most globally recognized models on customer satisfaction is the American customer satisfaction index model (ACSI). It measures the cause-and-effect relationship that runs from the antecedents of customer satisfaction level (customer expectation, perceived service quality, and perceived value) to its consequences (customer complaints and customer loyalty) (Fornell et al., 1996).

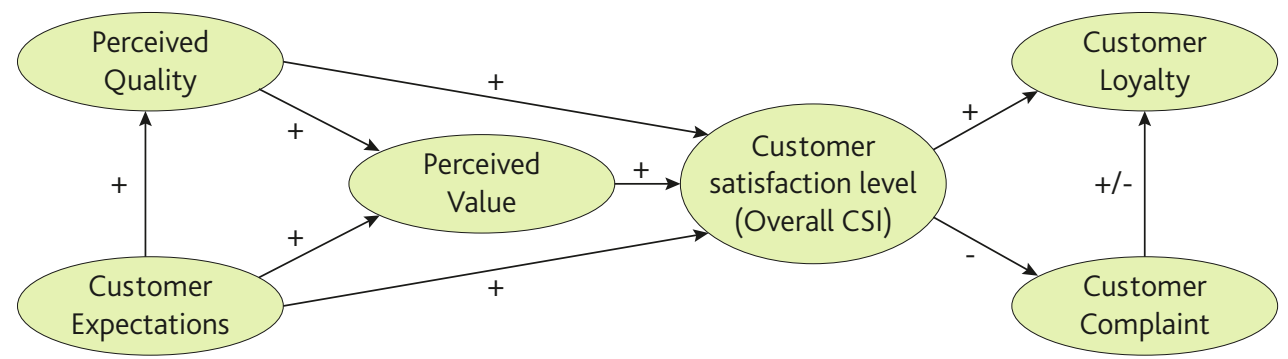

Figure 1. ACSI model

Source: Fomell et. al., 1996

The American Customer Satisfaction Index Model (ACSI Model) was developed in 1994 by Dr. Claes Fornell. The ACSI was based on the Swedish Customer Satisfaction Barometer, a model designed for a measurement of the Swedish economy by measuring consumer satisfaction (Fornell, 1992). The ACSI can be applied to economics at both the macro and micro levels. As the model can measure customer satisfaction based on their actual experiences, therefore it is used to measure product and service quality at the organization and industry levels. It also can be applied to marketing to enable it to reach more consumers.

A unique ability of this model is the ability to predict business outcomes (Fornell et al., 1996; Johnson et al. 1995). Many studies have shown a correlation between results from the application of the model and business outcomes (see for examples, Fornell et al., 1995; Martin, 1998).

Many countries that have adopted the ACSI model and developed it to suit the context of their country. These include New Zealand and Taiwan (Fornell et al., 1996), Austria, Norway (Andreassen, Lervik, 1999; Andreassen, Lindestad, 1998) and India through the Hexagon Consulting in 2015.

As online shopping is an experience different in many ways from traditional shopping, a new index for measuring electronic customer satisfaction index (e-CSI) was developed. This

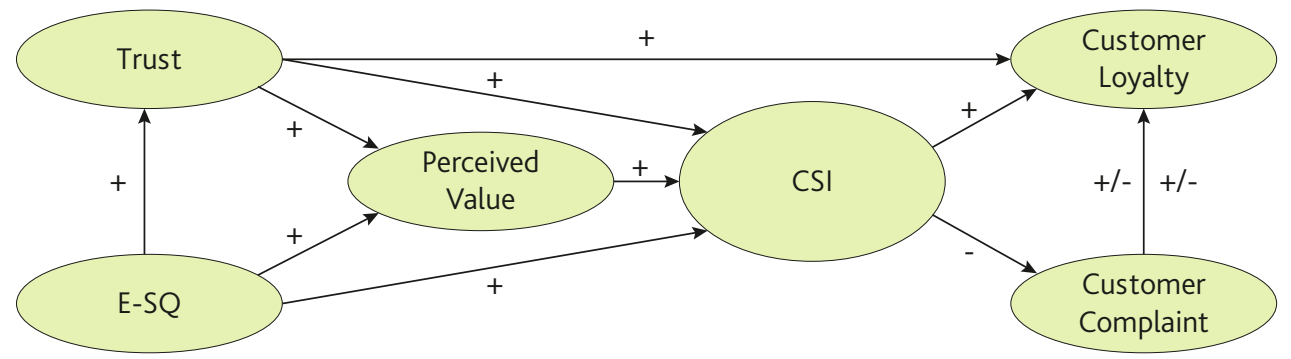

Figure 2. e-CSI model Source: Hsu, 2008 
model also allows the online retailer to understand the specific factors that significantly influence overall customer satisfaction by reading the causal relationship in the e-CSI model and the strategic management map. (S.H. Hsu, 2008).

The author(s) wants to adapt the existing literature on the dimensions of electronic service quality to online travel agencies in India to understand the impact these dimensions have on trust. Further, the researcher will measure the impact of trust on perceived value for the online travel agencies of India.

\section{Proposed Model}

The traditional service quality literature is dominated by people-delivered services. Thus, its results cannot be directly extended to electronic service quality contexts (Li et al., 2002). One of the most popular model's SERVQUAL model also cannot be considered as it has variables like "empathy" which may not be as significant as others which are not available like security, site aesthetics, etc. Fortunately, academic research has progressed in electronic service quality wherein definition, dimensions and measurement have been conducted in several papers. The researcher has identified the following dimensions of electronic service quality most appropriate for this study:-

a) Information availability - content is one of the most important aspects in the digital era. As there is no person to interface it is essential for the online travel agency to provide the most relevant, descriptive, up to date and accurate information including pictures. This information enhances the customer experience. Shankar et al. (2002) explained the positive relationship between information availability and trust.

b) Ease of use - an online travel agency has tons of information on its website and for a customer only some of it relevant. Hence it is critical for the website to be easy to use for the customer to gain access to the information which she/he desires by easily navigating and searching. McCloskey (2006) found that trust has a positive effect on the ease of use.

c) Privacy and security - this is critical to gain the confidence of the customer. The customer shares sensitive personal and financial information to the online travel agency which may be misused very easily. McCole, Rmasey and Williams (2010) established the relationship between privacy and security to trust as it creates a moderating effect on the trust.

d) Graphic style - the online travel agency may be easy to use and content rich, but it becomes essential for them to be presented in a way which the customer enjoys and finds attractive. Hsu S.H. (2008) showed that graphic style being one of the parameters of electronic service quality which in turn has a positive relationship with trust.

e) Fulfillment - the goal of any online travel agency is to encourage the customer to make a transaction on its website. Once the expected transaction takes place, it is essential that the customer receives their expected itinerary with accurate information along with the hotel/airline honoring the booking. It is essential that the online travel agency also has a robust support team which assists the customer as required and honors all expectations of the customer. Urban, Amyx and Lorenzon (2009) found order fulfilment was an important attribute that would foster trust on the website.

After completely understanding of the dimensions of electronic service quality the researcher proposed the model in figure 3. The hypotheses are as follows: 
$\mathbf{H}_{\mathbf{1}}$ : There is a positive relationship between information availability to trust being offered by the online travel agencies.

$\mathbf{H}_{2}$ : There is a positive relationship between fulfillment to perceived value being offered by the online travel agencies.

$\mathbf{H}_{3}$ : There is a positive relationship between ease of use to trust being offered by the online travel agencies.

$\mathbf{H}_{4}$ : There is a positive relationship between privacy and security to trust being offered by the online travel agencies.

$\mathbf{H}_{5}$ : There is a positive relationship between graphic style to trust being offered by the online travel agencies.

$\mathbf{H}_{\mathbf{6}}$ : There is a positive relationship between trust to perceived value being offered by the online travel agencies.

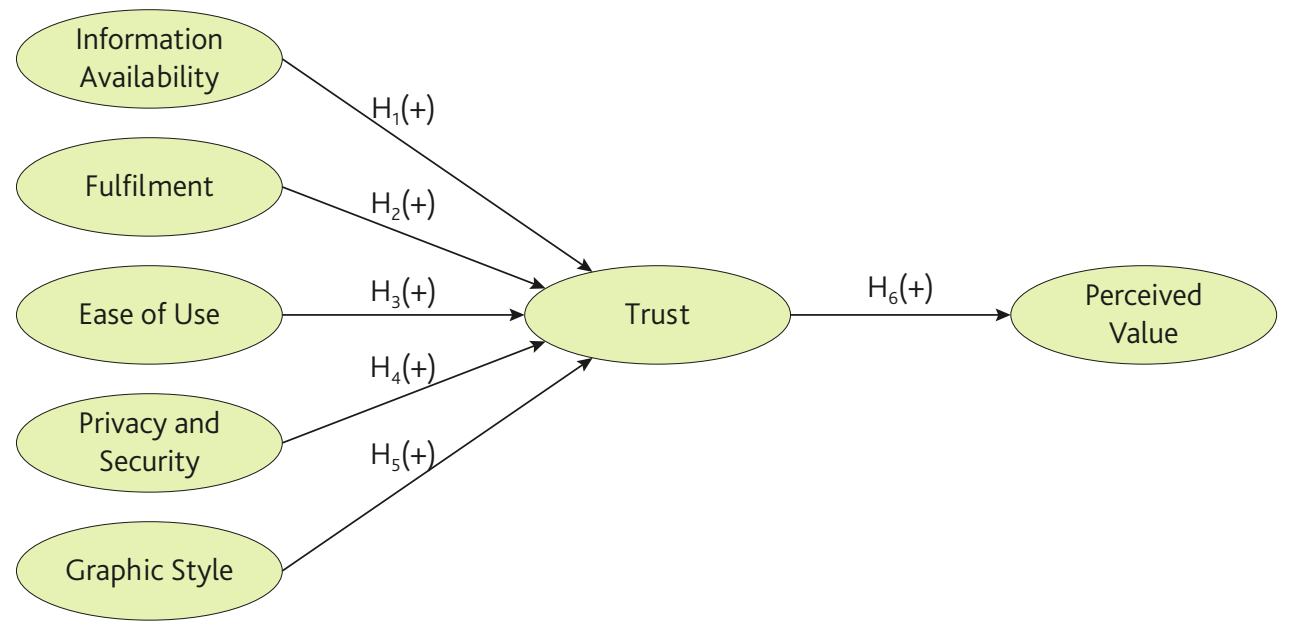

Figure 3. Proposed Model

\section{Methodology}

\section{Sample Size}

To determine the sample size the researcher used the widely acceptable - confidence level approach (Israel, 1992). By the end of the year 2016, the internet users in India are expected to reach 330 ,ooo,ooo out of which $38 \%$ users visit travel sites every month (Aranca, 2015). Hence the population size to be considered for the confidence level approach is $125,400,000$ who are going to visit online travel agencies. The researcher was comfortable with $95 \%$ confidence level with a margin of error of plus or minus five (also known as confidence interval). Based on this desired level of accuracy the sample size is determined to be 384 .

\section{Sampling Approach}

There are hundreds of online travel agencies in India, and each online travel agency has its unique customer interaction channels like the desktop website, mobile website and mobile app. The online travel agency leaders based on market share are the Indian online travel agencies Make- 
MyTrip (47\%), Yatra (20\%) and Cleartrip (20\%), which means that these three players hold an impressive $87 \%$ market share (Aranca, 2015). With a market share such as this, these three players would be ideal representatives of the online travel agencies in India. The researcher adopted a purposive sampling approach wherein three criteria were required for the participant to qualify for research. These were that the participant was an Indian and residing in India, the participant was 18 years and above, and the participant has used either MakeMyTrip or Yatra or Cleartrip in 2016. An online survey invitation was sent through email, SMS and WhatsApp through which a total of 733 people responded out of which 384 qualified and completed the survey.

The demographic characteristics of the 384-completed survey is as follows:

- Gender: $65.1 \%$ male and $34.9 \%$ female.

- Age: $0.9 \%$ below 18 years, $41.7 \% 18$ to 25 years, $42.2 \% 26$ to 35 years, $8.9 \% 36$ to 45 years, $3.7 \% 46$ to 55 years, $2.6 \% 56$ to 65 years and $0 \% 65$ and above years.

- Marital status: $49.9 \%$ married, $49.2 \%$ single, $0.9 \%$ divorced and $0 \%$ widower.

- Education level: $2.5 \%$ up to class 10th, $14.8 \%$ up to class 12 th, $50.3 \%$ up to bachelor degree, $25.4 \%$ up to master degree and $6.9 \%$ doctorate.

- Monthly salary: 16.9\% up to INR 25000, 24.5\% INR 25001-50000, 25.6\% INR 50001-75000, 15.5\% INR 75001-100000, 11.5\% INR 100001-150000 and 6\% INR 150001 and above.

\section{Scale and Questionnaire}

The scale used to measure the variables in the questionnaire in Table 1 will range from (1) to (5). The questionnaire is based on questions in the e-CSI model which were adjusted to make it applicable to this survey and the Indian context.

Table 1. Questionnaire

\begin{tabular}{|c|c|}
\hline \multirow{2}{*}{ Information Availability } & Do you think the online travel agency is providing relevant information? \\
\hline & Is the information being provided by the online travel agency up-to-date? \\
\hline \multirow{4}{*}{ Fulfillment } & Do you always receive your confirmed itinerary on-time? \\
\hline & Do you always receive the confirmed itinerary with the correct details? \\
\hline & Are you satisfied with the speed of responsiveness of the online travel agency? \\
\hline & Is the return and refund process smooth? \\
\hline \multirow{3}{*}{ Ease of Use } & Are you satisfied with the performance of customer service? \\
\hline & Does the online travel agency give you a logical layout of product list? \\
\hline & Are you satisfied with the online travel agency's search filters? \\
\hline \multirow{2}{*}{ Privacy \& Security } & Do you think the online travel agency will properly use of personal information? \\
\hline & Do you think the online travel agency maintains confidentiality of your information? \\
\hline \multirow{2}{*}{ Graphic Style } & Do you find the online travel agency's website attractive? \\
\hline & Do you find the online travel agency's appearance to be professional? \\
\hline \multirow{2}{*}{ Trust } & Do you think the online travel agency cares about customers? \\
\hline & Do you think the online travel agency is trustworthy? \\
\hline \multirow{2}{*}{ Perceived value } & Given the quality, how would you rate the price paid? \\
\hline & Given the price you paid, how would you rate the quality? \\
\hline
\end{tabular}

*Source: Compiled by Author 


\section{Reliability of data collected}

When using Likert-type scales, it is imperative to calculate and report Cronbach's alpha coefficient for internal consistency reliability for any scales or subscales one may be using. The analysis of the data then must use these summated scales or subscales and not individual items (Allen, Seaman, 2007).

For this dataset, the Cronbach's alpha is 0.908 which is reliable and good based on the thumb rule (George, Mallery, 2003).

\section{Results}

The proposed model consists of the measurement model and the structural model. The measurement model helps us estimate the loading values of the observed variables to investigate how well each observed variable represents the latent variable and the structural model, on the other hand, estimates the path coefficients of the latent variables and shows the causal relationship between the latent variables.

Table 2. Loading values of each observed variable

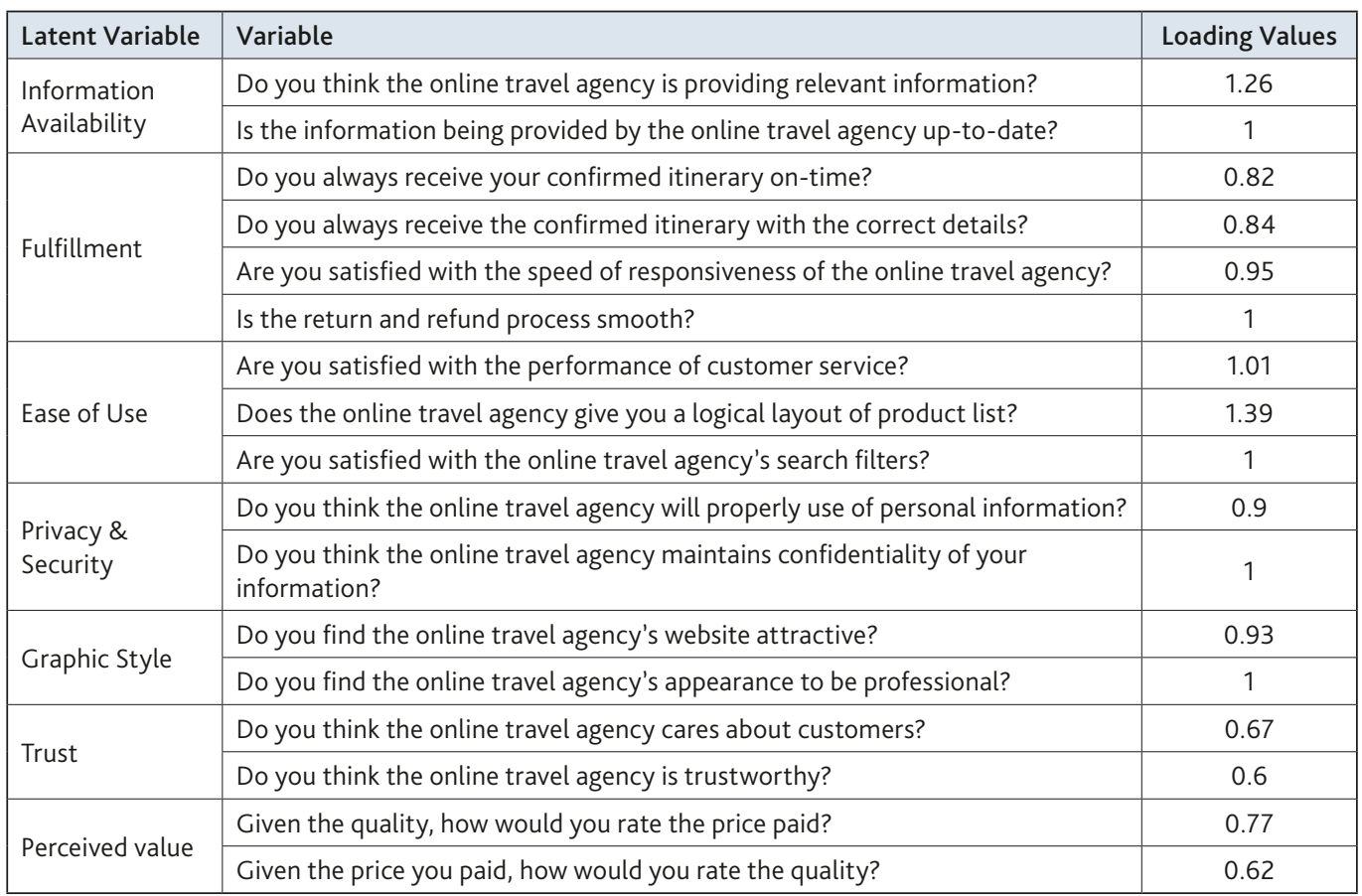

*Source: Compiled by Author

The model has chi-square value $=1182.046, \mathrm{df}=115, \mathrm{CFI}=0.55$ and $\mathrm{RMSEA}=0.156$. All the values fall within an acceptable range (Byrne, 2010) indicating that data collected is model fit. In the analysis of the structural model, all the six hypotheses are accepted. 


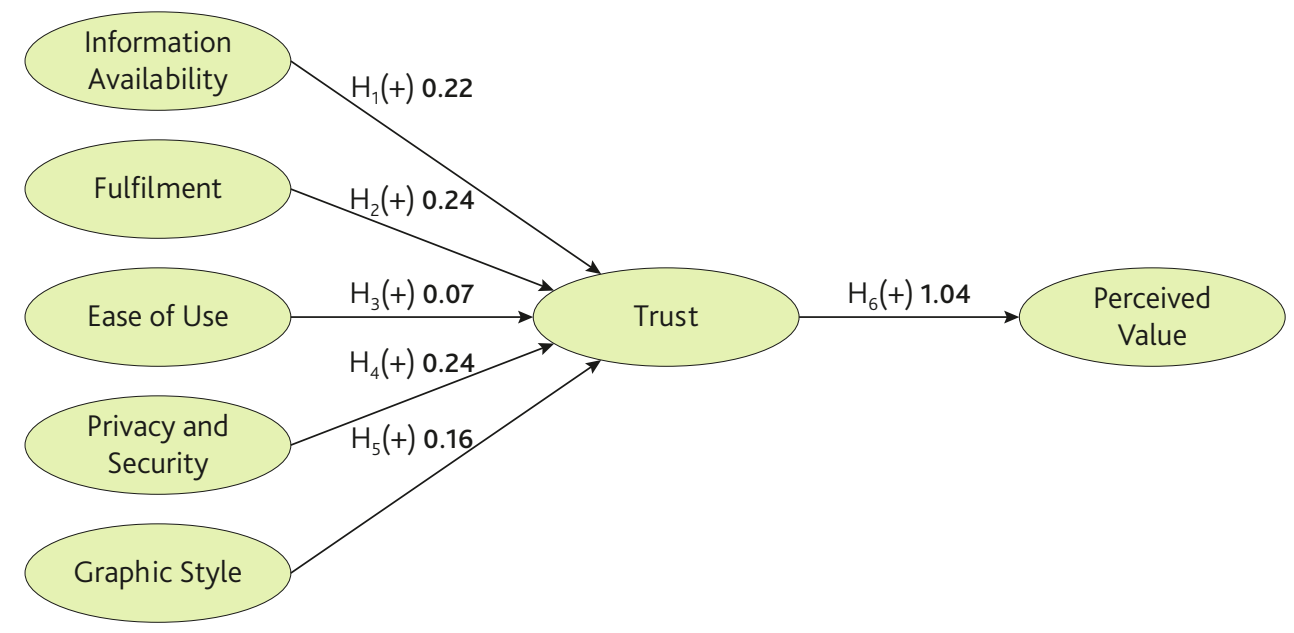

Figure 4. The relationship between the latent variables

$\mathbf{H}_{\mathbf{1}}$ : The regression weight from information availability to trust being offered by the online travel agencies is 0.22 is consistent with the positive relationship as previously hypothesized.

$\mathbf{H}_{2}$ : The regression weight from fulfillment to trust being offered by the online travel agencies is 0.24 is consistent with the positive relationship as previously hypothesized.

$\mathbf{H}_{3}$ : The regression weight from the ease of use to trust being offered by the online travel agencies is 0.07 is consistent with the positive relationship as previously hypothesized.

$\mathbf{H}_{4}$ : The regression weight from privacy and security to trust being offered by the online travel agencies is 0.24 is consistent with the positive relationship as previously hypothesized.

$\mathbf{H}_{5}$ : The regression weight from graphic style to trust being offered by the online travel agencies is 0.16 is consistent with the positive relationship as previously hypothesized.

$\mathbf{H}_{\mathbf{6}}$ : The regression weight from the trust to perceived value being offered by the online travel agencies is 1.04 is consistent with the positive relationship as previously hypothesized.

\section{Conclusion}

Trust is the key to success for any business especially in this digital era where the human interaction is negligible. The online travel agency needs to accomplish the difficult task of making every customer feel confident and secure enough so that they execute a transaction on their website. Naturally, every online travel agency, as well as new entrants, are continuously trying to improve their processes to gain the trust of the existing and potential customers through various strategies. It is common knowledge amongst the industry stakeholders that the key to success for online travel agencies is to provide the customers with a seamless and satisfactory experience. Every customer has their set of expectations from online travel agencies hence the online travel market is crowded as you have new entrants trying to capture niche markets by offering unique experiences to customers.

The online travel agencies have low margins, and there is cut throat competition amongst them. For them to survive and flourish in this challenging competitive environment, it is critical for them to excel in all dimensions of electronic service quality. 
It is proven from the proposed model that trust has a very positive impact on perceived value. The online travel agencies have limited resources and the business owners, and their managers would like to focus on the dimensions which have the maximum impact on trust. Based on the results the fulfillment of the transaction and privacy and security are the most important dimensions for the Indian customers. Although the online travel agencies need to focus on all dimensions to increase their trust and perceived value, focusing on these two dimensions of fulfillment and privacy and security will help improve the customer's confidence in their website more than the other dimensions.

The research focuses on the impact of the dimensions of electronic service quality on trust and the impact of trust on perceived value for the online travel agencies in India. The researcher hopes that the finding will help the existing online travel agencies and future entrants to have an in-depth understanding of electronic service quality and which dimensions they should focus on more. It will help to improve their business operations and investment focus, which in turn will lead to greater trust and perceived value.

The research will provide a basis for similar studies across other online businesses in India. Additionally, it will allow future researchers to build a more in-depth understanding of these dimensions. Researchers may explore further to know how these dimensions correlate to each other as well as how the regression weight changes (impact) when one dimension outperforms the other.

The findings are considered high on validity though there are certain inherent limitations to the research work carried out. The research has the limitation of time and resource as the topic is quite extensive. As the research has been carried out only through online survey method the scope of open-ended answers and other facets of the research may have got negated.

\section{References}

Allen, I.E., Seaman, C.A. 2007. Likert scales and data analyses Quality progress. Viewed on 31 October 2016, http://rube.asq.org/quality-progress/2007/o7/statistics/likert-scales-and-data-analyses.html

Andreassen, T. W., Lindestad, B. 1998. Customer loyalty and complex services: The impact of the corporate image on quality, customer satisfaction and loyalty for customers with varying degrees of service expertise. International Journal of Service Industry 9, 7-23. https://doi.org/10.1108/09564239810199923

Andreassen, T. W., Lervik, L. 1999. Perceived relative attractiveness today and tomorrow as predictors of future repurchase intention. Journal of Service Research 2, 164-172. https://doi.org/10.1177/109467059922004

Cronin, J.J., Brady, M.K., Hult, G.T.M. 20oo. Assessing the effects of quality, value and customer satisfaction on consumer behavioral intentions in service environments. Journal of Retailing 76(2), 193-218 https://doi.org/10.1016/soo22-4359(oo)ooo28-2

Chiou, W., Lin, C., Perng, C. 2011. A strategic website evaluation of online travel agencies. Tourism Management 32, 1463-1473. https://doi.org/10.1016/j.tourman.2010.12.007

Fornell, C., Johnson, M.D., Anderson, E.W., Cha J., Bryant, B.E. 1996. The American Customer Satisfaction Index: Nature, Purpose, and Findings. Journal of Marketing 6o, 7-18. https://doi.org/10.2307/1251898 
Cohen, E., Cohen, S.A. 2014. A mobilities approach to tourism from emerging world regions. Current Issues in Tourism 18, 11-43. https://doi.org/10.108o/13683500.2014.898617

Fornell, C. 1992. A National Customer Satisfaction Barometer: The Swedish Experience. Journal of Marketing 56, 6-21. https://doi.org/10.2307/1252129

Gliem, R.R., Gliem J.A. 2003. Calculating, interpreting, and reporting Cronbach's alpha reliability coefficient for Likert-type scales. Midwest Research to Practice Conference in Adult, Continuing, and Community Education. Viewed on 31 October 2016, http://www.ssnpstudents.com/wp/wp-content/uploads/2015/o2/Gliem-Gliem.pdf

George, D., Mallery, P. 2003. SPSS for Windows step by step: A simple guide and reference. 11.o update (4th ed.). Viewed on 31 October 2016, http://wps.ablongman.com/wps/media/ objects/385/394732/george4answers.pdf

Hsu, S. H. 2008. Developing an index for online customer satisfaction: Adaptation of American Customer Satisfaction Index. Expert Systems with Application 34, 3033-3042 https://doi.org/10.1016/j.eswa.2007.06.036

Johnson, M. D., Anderson, E. W., Fornell, C. 1995. Rational and adaptive performance expectations in a customer satisfaction framework. Journal of Consumer Research 21, 128-140. https://doi.org/10.1086/209428

Kaynama, S. A., Black, C.I. 200o. A proposal to assess the service quality of online travel agencies: An exploratory study. Journal of Professional Services Marketing 21, 66-88. https://doi.org/10.130o/jo9ov21no1_05

Kim, D.J., Kim, W.G., Han, J.S. 2007. A perpetual mapping of online travel agencies and preference attributes. Tourism Management 28, 591-603. https://doi.org/10.1016/j.tourman.2006.04.022

Kim, W.G., Lee, H.Y. 2004. Comparison of web service quality between online travel agencies and online travel suppliers. Journal of Travel and Tourism Marketing 17, 105-116. https://doi.org/10.1300/jo73v17no2_o9

Ladhari, R. 2010. Developing e-service quality scales: A literature review. Journal of Retailing and Consumer Services 17, 464-477.

https://doi.org/10.1016/j.jretconser.2010.06.003

Lehmann, E.E. 2001. Pricing behaviour on the WEB: Evidence from online travel agencies. SSRN Electronic Journal 1-20, 279-399.

https://doi.org/10.2139/ssrn.310413

Sánchez, M., García, G. 2015. Using online customer loyalty to gain competitive advantage in travel agencies. Journal of Business Research 68, 1638-1640.

https://doi.org/10.1016/j.jbusres.2015.02.009

McCole, P., Ramsey, E., Williams, J. 2010. Trust considerations on attitudes towards online purchasing: The moderating effect of privacy and security concerns. Journal of Business Research 63, 1018-1024. https://doi.org/10.1016/j.jbusres.2009.02.025

Mckloskey, D.W. 2006. The importance of ease of use, usefulness and trust to online consumer. Electronic Commerce, 1400-1417.

O'Connor, P. 2004. Privacy and the online travel customer: An analysis of privacy policy content, use and compliance by online travel agencies. Information and Communication Technologies in Tourism.

https://doi.org/10.1007/978-3-7091-0594-8_38 
Shankar, V., Urban, G.L., Sultan, F. 2002. Online trust: a stakeholder perspective, concepts, implications and future directions. Journal of Strategic Information Systems 11, 325-344. https://doi.org/10.1016/so963-8687(02)ooo22-7

Tsang, N.K.F., Lai, M.T.H., Law, R. 2010. Measuring e-service quality for online travel agencies. Journal of Travel and Tourism Marketing 27, 306-323. https://doi.org/10.1080/10548401003744743

Urban, G.L., Amyx, C.,Lorenzon, A. 2009. Online trust: State of the art, new frontiers and research potential. Journal of Interactive Marketing 23, 179-190. https://doi.org/10.1016/j.intmar.2009.03.001

Wilson, M.I. 200o. The fall of the mall? The impact of the online travel sales on travel agencies. Journal of Urban Technology 7, 43-58.

https://doi.org/10.1080/713684117 